\title{
Watchdog Journalism in Japan Rebounds but Still Compromised
}

\section{JEFF KINGSTON}

Keywords: Asahi, censorship, comfort women, Fukushima, Japan, \#MeToo, press freedom, sexual harassment, Shinzo Abe, watchdog journalism

$\mathrm{P}$ Rime Minister Shinzo Abe 's troubles in 2018 owe much to Japan's resilient liberal media. Between 2011 and 2017, the media was mostly on its back foot, losing credibility over its initial coverage about the Fukushima nuclear accident and withstanding heavy-handed efforts by Abe's government to pressure and intimidate the media into self-censorship (Kingston 2018a). Since early 2017, however, the liberal Asahi newspaper led the way in exposing two cronyism scandals involving private-school projects linked to Abe. It also exposed a series of cases revolving around information disclosure practices that revealed a culture of deception aimed at avoiding government accountability. These included a cover-up at the Defense Ministry regarding a Peace Keeping Operation (PKO) in South Sudan that violated legal constraints imposed by the Diet, and revelations about doctored data used to support Abe's proposed labor reforms. In these and other cases, the government's lack of transparency and mishandling of documents drew sharp public criticism. The press played its role of informing the public about these apparent transgressions while highlighting the arrogance of power that has undermined public trust in Abe; 80 percent do not believe his self-exonerating explanations about the cronyism scandals (Bloomberg 2018). Nonetheless, in September 2018 he won reelection to a third term as Liberal Democratic Party (LDP) president and is set to become Japan's longest serving prime minister. Popular support, however, is tepid, as monthly polls since 2013 by Japan's national broadcasting organization (NHK) indicate that about 50 percent of the public supports him due to a lack of alternatives rather than his virtues as a leader (about 15 percent) or the appeal of his policies (about 15 percent). Despite mixed reviews in the press, he has won a series of elections, and in politics that is what counts (Kingston 2018b).

\section{Taming of the Press}

Being a journalist in Japan is not dangerous like in many other countries where there is a risk of beatings, imprisonment, and murder. But there are other ways to curtail press 
freedom and cow journalists, especially when editors and publishers are often reluctant to stand up to the government. This subservience leads to self-censorship and at times excessive caution.

Abe has promoted various media-muzzling initiatives, such as the 2013 state special secrets law that enables bureaucrats to bury documents for up to sixty years with minimal oversight while introducing penalties of up to ten years' imprisonment for journalists accessing such documents and their government sources. In 2014, he appointed a crony with no media background to head NHK, who began his tenure by downplaying the comfort women system and embracing "Pyongyang rules," declaring that the nation's most influential broadcaster could not say "left" if the government said "right." That same year, the pro-Abe media orchestrated a campaign to discredit the Asahi newspaper with the government's encouragement (Fackler 2017).

The power of the media to make or break governments is precisely why the Abe government is keen to tame it by going after the government's critics. For example, in an off-the-record meeting with journalists in February 2015, Chief Cabinet Secretary Yoshihide Suga reportedly criticized an unnamed television program for bias, a warning that everyone understood was directed at TV Asahi. That same month Shigeaki Koga, a popular television pundit, claimed he was being fired from TV Asahi's popular news program due to his criticism of Abe. In 2015, NHK news anchor Kensuke Okoshi was also ousted due apparently to a clash with an Abe crony, while in 2016 Hiroko Kuniya's NHK show Close-up Gendai was terminated, part of a larger purge of Abe's critics as media organizations bowed to government pressure (Mulgan 2017; Nakano 2017).

Martin Fackler, a former New York Times Tokyo bureau chief, says, "Close-up Gendai was refreshing because it was one of the few efforts by NHK or any major media to do anything remotely approaching investigative, public-interest journalism, and in a prominent time slot." He adds, "Major media companies appear in full retreat under political and social pressure in the Abe era. Kuniya is just the latest high-profile journalist to be muzzled by media companies that appear to have grown incredibly risk-adverse, seeking to play it safe by just repeating what they are told in the press clubs, and shunning any topic or story that might draw criticism."

\section{Access Journalism}

David Kaye, the UN special rapporteur on the promotion and protection of the right to freedom of opinion and expression, issued a report on press freedom in Japan in June 2017 that blasted self-censorship, weak legal protections, access journalism, and media intimidation (Kaye 2017). His conclusions are consistent with previous assessments (Freeman 2000; Hall 1997; McCargo 1996). Kaye also slammed the kisha club (press club) system that embeds journalists at the ministries and agencies they are assigned to cover, enabling them to develop close ties and gain privileged access to official sources. The collaborative and sometimes collusive relationship implicit in this system hampers investigative journalism aimed at uncovering what authorities do not want the public to know. Hence journalists pull their punches and reinforce official narratives,

\footnotetext{
${ }^{1}$ Interview, January 2016.
} 
relying on "access journalism" and accepting the cooptation that entails. In this manner, the media suborns itself and becomes beholden to the officials and institutions they are supposed to cover without "fear or favor."

A senior writer for the Asahi Shimbun asserts that the role of the kisha clubs is exaggerated: "Kisha club is the place of official announcement and official agenda setting. It is not the place where you can find the most important information." He adds that "the news reporting which revealed the big scandals of the political power show well that in Japan, the press can do its job, though it is often said that Japanese press is well controlled by the government."

A Kyodo News reporter disagrees, arguing that "the Japanese government is now trying to provide benefits only to major media supporting Prime Minister Shinzo Abe’s administration by using the so-called kisha-club system, which excludes minor or internet media. That is really bad for freedom of press in Japan because information is sometimes manipulated by the government, preventing us from playing a role in monitoring the power."3

\section{SpotLight Journalism}

The film Spotlight won Oscars for best picture and best original screenplay at the 2016 Academy Awards. It is a film about the Boston Globe's investigative journalism unit that in 2003 won a Pulitzer for uncovering a sex abuse scandal involving scores of pedophile priests in the Boston diocese and a cover-up that reached into the higher echelons of the Catholic Church. It also became apparent that the Boston Globe was complicit in the church's cover-up.

Japan could use a few spotlights, but the establishment has the dimmer switch firmly in hand. Columbia University's Gerald Curtis, an expert on Japanese politics, says, "The big difference is that the US media stands up to power, as the Spotlight movie documents, and the Japanese media all too often kowtows to it. It is the pressure from people in senior management and middle-aged reporters who want to be considered for promotion ... who engage in censoring themselves and those who work for them.... The salaryman mentality keeps everyone in line." He adds, "There are many talented and courageous journalists in Japan, but the media's craven abdication of its responsibility to defend them and to protect freedom of speech is what needs to be put in the spotlight." ${ }^{4}$ Japanese investigative journalist laments that the public is overly tolerant of a coopted media, and the timidity and toadying involved. ${ }^{5}$

Publishers are wary of an unfavorable legal environment and a massive spike in financial penalties imposed on media companies in defamation lawsuits over the past twenty years (Repeta and Sawa 2017). This discourages the media from publishing stories that might provoke a lawsuit, thereby embracing self-censorship as a risk management strategy. These days, newspapers are primarily businesses where accountants, lawyers, and moguls rule the roost, taking some of the bite out of the watchdogs. Alas, it is a system that encourages journalists to keep their heads down, conveying little of what they

\footnotetext{
${ }^{2}$ Interview, May 2018.

${ }^{3}$ Interview, May 2018.

${ }^{4}$ Interview, April 2016.

${ }^{5}$ Interview, April 2016.
} 
know that might antagonize the powerful. And they have good reason to doubt that their employers will cover their backs in the event they do so.

The Abe government relies on media organizations and right-wing groups to assail its opponents. In 2014, an orchestrated campaign by neo-nationalist groups denouncing the liberal Asahi newspaper for its coverage of the comfort women story and hounding reporters with death threats enjoyed public support from Abe (Fackler 2017; Yamaguchi 2017). The media countercharge was led by the Yomiuri and Sankei newspapers, staunch conservative supporters of Abe's agenda. The relatively liberal Asahi has long been a powerful critic of the LDP and Abe's revisionist history and plans to revise the constitution. For example, in 2005 the Asahi reported on Abe's interference with an NHK documentary program about an international tribunal regarding comfort women and violence against women in war held in Tokyo at the end of 2000 (Nakano 2017). But embarrassing powerful politicians and antagonizing conservatives eager to rehabilitate Japan's wartime actions comes at a cost.

In August 2014, the Asahi issued a mea culpa for its coverage of the comfort women story of sexual slavery, apologizing for a handful of stories published in the 1980s and 1990s that relied on the discredited testimony of a World War II veteran. Asahi reporters confided to me they were angered by their management's weak response and disappointed that the newspaper capitulated rather than offering a robust rebuttal. The Yomiuri and Sankei pounced on this admission of wrongdoing even though they too had also published articles relying on the same erroneous testimony (see Yamaguchi 2017). They used this issue to discredit the Asahi and to promote the revisionist narrative that minimizes, mitigates, and denies the comfort women problem.

The Asahi has also been a bastion of opposition to Abe's agenda of constitutional revision and patriotic education and won the Japanese equivalent of the Pulitzer Prize for its post-2011 investigative reporting on the Fukushima nuclear disaster. This was the Asahi's Prometheus team that dug into the Fukushima disaster story and managed to uncover inconvenient truths much like the Boston Globe's Spotlight. This made it a target of the "nuclear village," or proponents of nuclear power in industry, politics, government, unions, media, and academia (Fackler 2017). The Abe government favors bringing Japan's idled nuclear reactors back online, and the Asahi's withering coverage exposing a culture of complacency, regulatory capture, and cost-cutting measures that compromised public safety impeded that agenda. The tables turned, however, when the Asahi investigative team became embroiled in scandal over a story it wrote on May 20, 2014, that suggested the workers at the Fukushima Daiichi plant had disobeyed the plant manager's orders and fled to the Fukushima Daini plant 10 kilometers away. This was a scoop based on testimony withheld from the public that was given by plant manager Masao Yoshida. The implication was that the exodus was akin to a mutiny and the workers had decamped because they feared for their lives, punching holes in the prevailing heroic narrative of the Fukushima Fifty of dedicated plant workers selflessly doing whatever was required to contain the nuclear disaster.

As Fackler (2017) argues, the nuclear village found this narrative useful and reassuring to a panicked public, while the Asahi exodus story raised awkward questions about plant safety in an emergency. Suspiciously, just as the Asahi was reeling from the orchestrated comfort women attacks, the Yomiuri and Sankei were leaked copies of Yoshida's testimony kept at the prime minister's office (Fackler 2017). They attacked the Asahi 
over its interpretation of the worker exodus, asserting that they had not disobeyed orders and that the movement of workers was orderly. In fact, Yoshida says his instructions were probably garbled and misinterpreted; he never actually told workers to leave the Fukushima Daiichi site, but also did not tell them not to leave, so the Asahi overstated the situation in a somewhat sensationalist way. Given the hammering over its reporting on sex slavery, and sharp declines in circulation, Asahi management was in damage control mode. As a result, it retracted the exodus story and punished key reporters on the Prometheus "spotlight" team while derailing the Fukushima investigation. The liberal media did not come to the Asahi's defense and showed no solidarity despite the obviously orchestrated nature of the attacks. It is worth bearing in mind that this investigative team was established in part to regain the public's trust, lost in the immediate aftermath of the March 2011 nuclear reactor meltdowns when the media was complicit in the cover-up, downplaying the severity of Japan's Chernobyl for two long months.

\section{AsAH's ReVEnge}

The Asahi has been at the forefront of holding the government accountable since early 2017, recovering from the 2014 orchestrated campaign by pro-Abe media to discredit it. Two cronyism scandals have dogged the Abe cabinet since early 2017. The first involved a sweetheart land deal in which a school operator, Moritomo Gakuen, secured public land near Osaka at an 86 percent discount. The owner, Yasunori Kagoike, had connections to Abe's wife and pledged to name the school after Mr. Abe because it shared the prime minister's commitment to promoting patriotic values. The second scandal involved a close friend of Abe, Kotaro Kake, who was granted special permission to open a veterinary school, the first granted in half a century. Memos by local officials detail their meetings with emissaries from the prime minister's office and their lobbying efforts that suggested the Kake vet school project had Abe's backing. It is alleged that in both these school scandals, officials acted with the knowledge that their actions would be appreciated. The media made much of the concept of sontaku, in these cases officials acting without explicit orders in order to curry favor with Abe. Since Abe has moved to centralize high-ranking bureaucratic promotions in the Kantei (the prime minister's office), it is apparent that, "bureaucrats are increasingly concerned about not challenging the Kantei ... and that public servants now prioritise saving their necks, being promoted and brown-nosing the people in power for that purpose" (Mulgan 2018).

Concerted press efforts to uncover the truth about both the school scandals have undermined trust in and support for Abe as he and others involved have been caught out repeatedly in contradictions and implausible denials and assertions. Various documents and memos have been produced and reported that verify allegations that the Abe administration used its influence in both cases to secure a favorable outcome (Nikkei Asian Review 2018). At one point, his poll ratings went into a nosedive, dropping to only 26 percent in a Mainichi poll, down from 60 percent earlier in the year (Kingston 2017; Mainichi 2017).

In response, Abe called snap elections to gain a public mandate, a gamble that paid off as a fractured and unprepared opposition imploded while missile launches from North Korea rallied support. It seemed like his troubles were behind him, but starting in early 
January 2018 the media resumed a steady drumbeat on the various scandals. The uncovering of doctored data in support of Abe's labor reform law bill and revelations about a tampered document submitted to the Diet related to the Moritomo case intensified media coverage and reignited public anger. The Ministry of Finance (MOF) had submitted an altered document to the Diet in 2017 to support the contention that Abe was not involved in the land sale, but then the media revealed that someone had erased the names of Abe, his wife, and other LDP heavyweights that had been scrawled on the documents with brief notes. Subsequently, in May 2018 the MOF came clean and released all of the "lost" Moritomo records and memos that tie Abe's wife to the scheme and contradict Diet testimony exonerating him. These various scandals suggest that the media is doing its job and informing the public about what the powers that be do not want them to know.

David McNeill, a journalist for The Economist and the Irish Times, comments, "On Moritomo and Kake, the liberal media, frustrated by five years of Abe government, have been more aggressive in pursuing what to outsiders look like clear cut cases of cronyism." Alas, "what has been depressing is the way the coverage falls along traditional right-left lines, with the Asahi/Mainichi and Tokyo Shimbun taking a more confrontational approach vs the Sankei/Nikkei/Yomiuri soft-peddling." Taking a cue from President Donald Trump, "since the scandals broke, the prime minister, his deputy and other senior members of the LDP have singled out the Asahi by name and said the media is at war with the government." He adds, "I'm surprised by the lack of media outrage that Yasunori Kagoike (the central figure in the Moritomo scandal) has been in Osaka Detention House since July 2017. Even during the worst periods of detention without trial and Ziplock courts in Northern Ireland, defendants got out into the sunshine once in a while-at least until they were proved guilty." ${ }^{6}$ Kagoike and his wife were finally granted bail after spending ten months in detention.

A senior writer for the Asahi Shimbun maintains that the scandal coverage shows that "the freedom of press in Japan is not dying. At least not dead yet. I know that there are newspapers, TV news programs, net-news, journalists, and commentators that are very conformist to the government line. Because of that, there are more and more people who are disappointed with the media."7

Yasuomi Sawa, the only Japanese journalist I interviewed who agreed to be identified, is a Senior Writer, Investigative and In-Depth Reporting, for Kyodo News. He agrees that "the Kake and Moritomo coverage by the Asahi Shimbun and other media shows that press freedom here is still working. Most notably, it is a dramatic victory for the Asahi Shimbun that it successfully bit back." ${ }^{8}$ And yet, press freedom remains compromised by rampant sexism.

\section{\#MeToo Lost in Translation}

While the outing of Harvey Weinstein spurred the \#MeToo movement in the United States, ricocheting through Hollywood and far beyond, in Japan it has so far been driven

\footnotetext{
${ }^{6}$ Interview, May 2018.

${ }^{7}$ Interview, May 2018.

${ }^{8}$ Interview, May 2018.
} 
by abuses in the media industry with limited consequences across society. Japan's \#MeToo movement has been slow to develop despite widespread perceptions that sexual harassment is endemic. In a deeply patriarchal society where male gatekeepers have extensive influence over careers and media coverage, the disincentives for women to come forward are enormous. Moreover, the prospects for significant change appear limited, discouraging women from risking their careers, privacy, and reputations.

Shiori Ito became the face of Japan's \#MeToo movement in 2017 when she published Black Box, a book about her being raped by a fellow journalist and biographer of Abe. They met to discuss her career prospects and options, but she says it ended with him spiking her drink and dragging her semi-conscious body into his hotel, a scene captured on the hotel's video footage, where he raped her (McNeill 2017). The taxi driver also backed up her version of events. She endured a traumatic runaround with the police, who advised her to forget the incident. Instead she pressed on, enduring a humiliating reenactment with a dummy as police snapped photos to gather evidence.

Ito filed a criminal complaint in April 2015, less than a month after the alleged incident. Then, as McNeill (2017) reports, "Two months after the assault, an arrest warrant was issued for quasi-rape (where consent is impossible) against Noriyuki Yamaguchi, then the Bureau Chief of Tokyo Broadcasting System (TBS)'s Washington Bureau. On June 8, 2015, investigators waited to serve the warrant to Yamaguchi at Narita Airport. Instead, Shiori says, one of the investigators called her and said he had been ordered to let Yamaguchi go." Shiori was offered a "settlement" from Yamaguchi, although he continues to deny the allegations.

The mainstream media initially gave little coverage to the story, but the weekly tabloids smelled a conspiracy in the sidelining of the investigation and arrest, noting that Yamaguchi was close to Abe and shared his right-wing revisionist views downplaying and denying the comfort women system of institutionalized mass rape. Ito's ordeal triggered a debate about how victims are treated poorly in Japan, attracting extensive media attention. However, she was also subject to vicious online harassment.

In April 2018, a young female journalist, inspired by Ito, ignited a political storm that forced the resignation of the top bureaucrat at the MOF. It is no secret that media organizations trade on the good looks of young female reporters to elicit information from top officials. Those assigned to such reporting duties are under pressure to get information and how they do so is up to them. Junichi Fukuda, the MOF vice-minister who resigned due to the scandal, apparently had a notorious reputation for sexually harassing young reporters. Knowing this, the reporter's female supervisor at TV Asahi did not encourage her to play the game of going out for dinner and drinks with sources. But after a year, TV Asahi apparently felt that other media organizations were getting an advantage and she was encouraged to get inside information from Fukuda. While cultivating ties to Fukuda, the reporter was subject to sexual harassment but alleges her supervisor was not supportive. To prove her point, the next time she went out for drinks with Fukuda the reporter surreptitiously taped their conversation. He suggested tying her up and having an affair, and also asked if he could touch her breasts. Apparently her supervisor scolded her and declined to air a report about Fukuda's proclivities. The reporter wanted the story to get out, so she provided the information and tape to a weekly tabloid magazine where salacious scandals are first broken. While the mainstream media is happy to cover a scandal once exposed, it often refrains from leading the charge at the outset. 
Fukuda brazenly denied the revelations even after being confronted with the tape. Taro Aso, the Minister of Finance, had his back, demanding that the reporter come forward while also denying that what was reported constituted criminal sexual harassment. The men's club circled the wagons. The victim was subject to online harassment and was accused of unethical conduct. TV Asahi held a press conference where its representatives condemned Fukuda's actions, and the MOF's mishandling of her case, while also rebuking their own reporter for sharing information with another news outlet.

Leo Lewis, a veteran journalist at the Financial Times, condemns TV Asahi “for not protecting its own. Having put her in this vulnerable position it ought to have had her back. She needed to have the editor's support and didn't get that. The rest of the media also showed little solidarity over this." In his view, "the sexism issue is a sideshow to the greater nastiness of TV Asahi hanging its employee out to dry.",

The same week that the Diet passed a nonbinding resolution promoting women's participation in politics, on May 18, 2018, the Abe cabinet released a statement that criminal sexual harassment does not exist because Japan has no such law. This statement was issued to counter criticism of Finance Minister Aso, who attracted harsh media coverage for his repeated remarks denying that Fukuda was guilty of criminal sexual harassment. The effort to defend Aso along these lines cast doubt on the cabinet's sense of responsibility for the affair, portraying the absence of such a law as some kind of vindication rather than a priority to be rectified.

Aurelia George Mulgan, a Japan specialist at the University of New South Wales in Australia, comments: "A structural cause in this case is the press club system. TV Asahi was frightened about being denied access to the MOF. The Japanese establishment has a bad habit of freezing you out if you don't play according to their rules." ${ }^{\prime 10}$ Sophia University's Koichi Nakano explains that Asahi TV's handling of the Fukuda affair highlights the fact that "collusion between the press club reporters of the mainstream media and the government is real. Fukuda knew full well that he could get away with it because no news organization would dare report on his horrid conduct. The matter was only exposed in the less respectable weekly magazine, and only after the MOF was under attack from all corners (and scapegoated even by the LDP political masters, who are now eager to put the blame on the MOF bureaucrats for everything)." In his view, "the news industry is deeply and disgustingly sexist and misogynistic. The silence was imposed not just by Fukuda and the MOF but also by the male cadres within Asahi TV. \#MeToo accusations of the powerful continue to be very risky in the Japanese media because the male-dominated companies are unlikely to offer the victims support and cover they need."11

The handling of the Fukuda scandal manifests a patriarchal system designed to serve and protect the powers that be, with the MOF and TV Asahi being elite institutions that enjoy reciprocal benefits. Jeopardizing this relationship over a sexual harassment story is unlikely given what is at stake. There is patriarchal denial about the abnormal working conditions faced by these so-called kunoichi (female ninjas) who are expected to put up with lewd behavior by powerful men. It is, as one media informant said, "part of

\footnotetext{
${ }^{9}$ Interview, May 2018.

${ }^{10}$ Interview, May 2018.

${ }^{11}$ Interview, May 2018.
} 
the game. They are not exactly dangled as bait, but there is an assumption that they are more likely to be remembered and singled out for special attention by officials." 12 Problematically, little of the information gained by such means ever sees the light of day, so women are being put in harm's way for no reason other than cultivating and maintaining good institutional relationships.

Oddly, there are parallels between the Spotlight case of an institutionalized cover-up of sexual abuse by Catholic priests in Boston and the behavior of bureaucrats in Japan. Like notorious pedophile priests, Fukuda’s behavior was well known. In both cases, there is considerable media complicity in the cover-ups that is due to longstanding, close institutional ties and fear of crossing such an influential institution. The potential for unpleasant consequences of exposing the dirty laundry outweighed the media's duty to promote accountability by exposing abuses of power. Finally, the Boston Globe overcame that fear, but it remains to be seen if the Japanese media has reached a similar tipping point. Probably not. The weekly magazines that broke this story are not allowed into the press clubs and make their name and profits by trading in titillating stories. They merely exposed what was widely known about Fukuda but not reported by a meek mainstream media. This division of labor remains resilient.

As Kana Inagaki and Leo Lewis wrote in the Financial Times, "The culture of silence and resignation is fueled by a sense of duty and fear of losing sources, giving rise to generations of female reporters who have tolerated various kinds of sexual abuse from kisses, breast touching, to knee rubs in taxis" (Inagaki and Lewis 2018). Lewis does not think that the \#MeToo movement gained much momentum. ${ }^{13}$ The Fukuda scandal created a moment of national reflection and outrage, but the mainstream media tended to treat this as a josei mondai (women's problem) and thus not a priority, rather than a national disgrace. Abe grandstands on "womenomics" and speaks frequently of empowering women, but in this case, he could not find his voice to speak out for the vulnerable or condemn those who trade on their power to inflict indignities on women. Indeed, the reporter was subject to a smear campaign and Abe never rebuked Aso for suggesting that Fukuda was framed in a honeytrap.

Sexual harassment and gender discrimination in the media are deeply embedded, systemic, and widely tolerated. The Nikkei newspaper conducted a poll in May 2018 about sexual harassment covering 1,000 working women. More than 60 percent of victimized women had put up with sexual harassment without reporting it to superiors or colleagues. Sagami University professor Toko Shirakawa argues that this means "that many victims cannot even consult their employers out of fear that their jobs could be negatively affected" (Shirakawa 2018). As business consultant Nobuko Kobayashi (2018) explains, "reporting often presents a high hurdle as a victim often does not want to be seen as a 'complainer' or is afraid of retaliation.”

In an Internet survey focusing on the media industry conducted by Kyodo News, of the 103 women and 4 men who responded, 102 reported experiencing sexual harassment and 96 percent said it happened on multiple occasions (Kyodo 2018). Only 36 percent reported that they consulted with others, mostly because they did not want to be seen

\footnotetext{
${ }^{12}$ Interview, May 2018.

${ }^{13}$ Interview, May 2018.
} 
as troublesome and had low expectations about whether the matter would be properly addressed. Of those harassed, 74 said the cases involved people they were meeting for their work, 44 by bosses and 35 by senior colleagues.

"No More Sexual Harassment in Media" presented a groundbreaking report in May 2018 documenting 150 cases of female reporters who were subjected to sexual harassment (McCurry 2018). This report, put together following Fukuda's resignation, details harassment by government officials, police, and local politicians who routinely ask female journalists for sexual favors in exchange for information and sometimes assault them. When the women reported the incidents to their employers, they say they were ignored or "treated inappropriately."

Lewis cautions that news cycles have a way of shifting attention rather abruptly as events unfold and new improprieties emerge. ${ }^{14}$ Problematically, to the extent that sexual harassment in the media industry is the story, the press must cooperate in its own skewering. Given that there has been such longstanding tolerance of sexism in the industry, it is hard to expect a sustained focus on media complicity in institutionalized degradation (Adelstein 2018).

Does this sexual harassment of reporters influence freedom of the press? The widespread tolerance of this endemic abuse is suggestive of the subordinate relationship between the media and representatives of the state. This submission is in itself a sign of capitulation that undermines freedom of the press. To the extent that officials can treat female journalists so contemptuously with impunity, the media acquiesces to such indignities and thus conspires in its own subordination. If officials know they can get away with such behavior without editors standing up for their reporters, other abuses also look negotiable. Where does the line get drawn? This murkiness is a hotbed for collusion and tolerates a cocoon of impunity that the Fourth Estate should be unraveling. Freedom from intimidation and harassment are essential to press freedom, and this is undermined by a media landscape that remains hostile to female journalists' dignity and professionalism.

\section{Concluding Remarks}

The investigative reporting on a series of scandals engulfing the Abe administration since 2017 suggests that the press is fulfilling its watchdog role. From 2013 to 2017, Abe's minions went after his critics in the media, helped oust a few prominent newscasters and pundits while sending warnings to the media about the cost of crossing him. Under Abe, there has been backsliding on transparency and information disclosure, but the media has exposed how ministries have mishandled, doctored, "lost," and otherwise tampered with records and data to support Abe and derail investigations into wrongdoing. Thus, the media has been doing its job despite Team Abe's concerted efforts to rein it in.

Lewis thinks that the journalistic ethos in the United States about the press playing a central role in democracy and showing solidarity over any attempts to impinge on press freedom is not as widespread in Japan. Japanese journalists, in his view, "are hungry for good stories and bring to light even trivial cases of corruption," but do not share their US

\footnotetext{
${ }^{14}$ Interview, May 2018.
} 
colleagues' ideological zeal about press freedom. ${ }^{15}$ In Japan, he argues, journalists take the long view, nurture relationships, and expect a certain degree of give and take while working under the assumption of cyclical patterns in the press freedom landscape.

The media has been complicit in covering up abuses by powerful men who sexually harass female reporters, an affront to their professionalism and a threat to press freedom. Such craven practices ensure that the media punches below its weight and raise questions about what else gets swept under the national tatami mat. There are concerns that the current \#MeToo moral panic may go the way of previous outbursts of outrage over bullying (ijime), joshi kosei (compensated dating involving secondary school girls), and violent training techniques in sports (taibatsu). After the initial explosion of indignation over abuses that most people knew about, but chose to ignore, media attention fades and moves on to the next moral panic and another round of handwringing and cosmetic reforms.

Perhaps but if one takes the long view, the media does help mainstream new norms and expectations and pressures for legal reforms. For example, the media played a significant role in drawing attention to domestic violence in the 1990s, transforming it from a family problem to a matter for state intervention. The media also advocated for reforms that subsequently facilitated an expansion of civil society after the 1995 Kobe quake and helped to make information disclosure and transparency the sine qua non of good governance (Kingston 2004). Such changes happened rather rapidly against the odds, so it may be too soon to discount the potential consequences of \#MeToo.

The editor in charge of the Asahi's "Prometheus" unit on the Fukushima nuclear debacle posted a sign to motivate his reporters: "No More Pooches." Some journalists were offended by the implications, while others found the admonition inspiring. Revelations about Abe's scandals indicate that the media can be a powerful watchdog when it chooses to do so, but institutionalized timidity ensures that the lapdog image lingers. The reliance on access journalism and excessive deference, along with journalists' selfperception as players in the business of government, constrains press freedom.

Finally, media groups and editors have been remiss in not standing up for their reporters. Kaye (2017) noted that the dozens of Japanese journalists he interviewed did not want to be quoted by name, not because they feared government retribution, but because they worried about a backlash from their own employers and editors. These inclinations towards self-censorship and anticipating what the government would object to are bad habits that undermine press freedom and the media's role in informing the public about what the powerful prefer they not know.

\section{List of References}

Adelstein, Jake. 2018. "In Japan Its Now WithYou, not MeToo-But Sexual Harassment Is Still a Venerated Tradition." Daily Beast, May 21. https://www.thedailybeast.com/ in-japan-its-now-withyou-not-metoobut-sexual-harassment-is-still-a-veneratedtradition (accessed September 29, 2018).

${ }^{15}$ Interview, May 2018. 
Bloomberg. 2018. "Support for Japan's Abe Plummets to Record Low in Two Polls." March 18. https://www.bloomberg.com/news/articles/2018-03-19/support-for-japans-abe-plummets-to-record-low-in-two-polls (accessed October 5, 2018).

Fackler, Martin. 2017. “A Pooch After All? The Asahi Shimbun’s Foiled Foray into Watchdog Journalism.” In Press Freedom in Contemporary Japan, ed. Jeff Kingston, 40-55. Abingdon, UK: Routledge.

Freeman, Laurie Anne. 2000. Closing the Shop: Information Cartels and Japan's Mass Media. Princeton, N.J.: Princeton University Press.

Hall, Ivan. 1997. Cartels of the Mind: Japan's Intellectual Closed Shop. New York: W.W. Norton.

Inagaki, Kana, and Leo Lewis. 2018. "Japan Pushes Back against \#MeToo Movement." Financial Times, May 3. https://www.ft.com/content/d64bd404-4a08-11e8-8ee8cae73aab7ccb (accessed October 5, 2018).

KaYe, David. 2017. "Report of the Special Rapporteur on the Promotion and Protection of the Right to Freedom of Opinion and Expression on His Mission to Japan." UN Human Rights Council. http://hrn.or.jp/wpHN/wp-content/uploads/2017/05/A_HRC_35_22_ Add.1_AUV.pdf (accessed September 29, 2018).

Kingston, JefF. 2004. Japan's Quiet Transformation: Social Change and Civil Society in the Twenty-First Century. Abingdon, UK: Routledge.

- 2017. "Beleaguered Abe on the Ropes as Support Weakens." Japan Times, August 5. https://www.japantimes.co.jp/opinion/2017/08/05/commentary/beleaguered-abe-ropessupport-weakens/\#.WwJBay-B1PM (accessed September 29, 2018).

—. 2018a. Japan. Cambridge, UK: Polity Press.

- 2018b. “Abe’s Woeful Record of Policy Drift.” Nikkei Asian Review, September 18. https://asia.nikkei.com/Opinion/Abe-s-woeful-record-of-policy-drift (accessed October 5, 2018).

Kobayashi, Nobuko. 2018. “\#MeToo Finally Comes to Japan.” Nikkei Asian Review, May 18. https://asia.nikkei.com/Opinion/MeToo-finally-comes-to-Japan2 (accessed September 29, 2018).

Kyodo. 2018. "Japan Survey Suggests 96\% of Sexually Harassed Media Workers Are Targeted More Than Once.” Japan Times, May 17. https:/www.japantimes.co.jp/news/ 2018/05/17/national/japan-survey-suggests-96-sexually-harassed-media-workerstargeted/\#.WwZMgy-B2b8 (accessed September 29, 2018).

MAINICHI. 2017. "Cabinet Approval Rating at 26\%, Lowest Since Abe Returned to Power in 2012: Poll.” July 24. https://mainichi.jp/english/articles/20170724/p2a/00m/0na/ 010000c (accessed October 5, 2018).

McCargo, Duncan. 1996. "The Political Role of the Japanese Media." Pacific Review 9 (2):251-64.

McCurry, Justin. 2018 “Japan Sexual Harassment Survey Reveals 150 Allegations by Women in Media.” Guardian, May 22. https://www.theguardian.com/world/2018/ may/22/japan-sexual-harassment-survey-reveals-150-allegations-by-women-in-media (accessed September 29, 2018).

McNeIll, David. 2017. "Murder of the Soul - Shiori and Rape in Japan.” Asia Pacific Journal: Japan Focus 15(15, no. 3). https://apjjf.org/2017/15/McNeill.html (accessed September 29, 2018).

Mulgan, Aurelia George. 2017. "Media Muzzling under the Abe Administration.” In Press Freedom in Contemporary Japan, ed. Jeff Kingston, 17-29. Abingdon, UK: Routledge. 
— . 2018. "Abe Getting Schooled by Moritomo Scandal.” East Asia Forum, March 21. http:/www.eastasiaforum.org/2018/03/21/abe-getting-schooled-by-moritomo-scandal/ (accessed September 29, 2018).

Nakano, Koichi. 2017. "The Rightwing Media and the Rise of Illiberal Politics in Japan." In Press Freedom in Contemporary Japan, ed. Jeff Kingston, 30-39. Abingdon, UK: Routledge.

Nikkei Asian Review. 2018. “Lost’ Documents Mark New Twist in Abe Scandal.” May 24. https://asia.nikkei.com/Politics/Lost-documents-mark-new-twist-in-Abe-scandal (accessed October 5, 2018).

Repeta, Lawrence, and Yasuomi Sawa. 2017. "Chilling Effects on News Reporting in Japan's 'Anonymous Society.”' In Press Freedom in Contemporary Japan, ed. Jeff Kingston, 93-109. Abingdon, UK: Routledge.

Shirakawa, Tоко. 2018. “How to Stop Sexual Harassment.” Japan Times, May 22. https:// www.japantimes.co.jp/opinion/2018/05/22/commentary/japan-commentary/stopsexual-harassment/\#.WwZPKC-B2b8 (accessed September 29, 2018).

Yamaguchi, Tomomi. 2017. "Press Freedom under Fire: 'Comfort Women,' the Asahi Affair and Uemura Takashi.” In Press Freedom in Contemporary Japan, ed. Jeff Kingston. Abingdon, UK: Routledge. 